\title{
Molecular basis of protein structure in combined feeds (hulless barley with bioethanol coproduct of wheat dried distillers grains with solubles) in relation to protein rumen degradation kinetics and intestinal availability in dairy cattle
}

\author{
X. Zhang ${ }^{1}$ and P. Yu ${ }^{2}$ \\ Department of Animal and Poultry Science, College of Agriculture and Bioresources University of Saskatchewan, Saskatoon SK S7N 5A8, \\ Canada
}

\begin{abstract}
The objectives of this study were to reveal protein molecular structure in relation to rumen degradation kinetics and intestinal availability in combined feeds of hulless barley with bioethanol coproduct [pure wheat dried distillers grains with solubles (DDGS)] at 5 different ratios (100:0, 75:25, 50:50, 25:75, and 0:100) in dairy cattle. The parameters assessed included 1) protein chemical profiles, 2) protein subfractions partitioned by the Cornell Net Carbohydrate and Protein System, 3) in situ protein degradation kinetics, 4) truly absorbed protein supply in the small intestine (DVE), metabolizable protein characteristics and degraded protein balance (OEB), 5) protein molecular structure spectral profiles, and 6) correlation between protein molecular structure and protein nutrient profiles and metabolic characteristics. We found that 1) with increasing inclusion of wheat DDGS in feed combinations, protein chemical compositions of crude protein $(\mathrm{CP})$, neutral detergent-insoluble $\mathrm{CP}$, acid detergent-insoluble $\mathrm{CP}$, and nonprotein $\mathrm{N}$ were increased, whereas soluble $\mathrm{CP}$ was decreased linearly; $\mathrm{CP}$ subfractions $\mathrm{A}, \mathrm{B}_{3}$, and $\mathrm{C}$ were increased linearly, but $\mathrm{CP}$ subfractions $\mathrm{B}_{1}$ and $\mathrm{B}_{2}$ were decreased; truly digestible $\mathrm{CP}$ increased but total digestible nutrients at $1 \times$ maintenance decreased linearly; protein degradation rate was decreased without affecting potentially soluble, potentially degradable, and potentially undegradable fractions, and both rumendegradable protein and rumen-undegradable protein were increased; by using the DVE/OEB system, the DVE and OEB values were increased from 98 to 226 $\mathrm{g} / \mathrm{kg}$ of dry matter and -1 to $105 \mathrm{~g} / \mathrm{kg}$ of dry matter, respectively; 2) by using the molecular spectroscopy
\end{abstract}

\footnotetext{
Received December 29, 2011.

Accepted January 30, 2012

${ }^{1}$ Current address: Department of Animal Science, Tianjin Agricultural University, Tianjin, 300384, China.

${ }^{2}$ Corresponding author: peiqiang.yu@usask.ca
}

technique, the spectral differences in protein molecular structure were detected among the feed combinations; in the original combined feeds, amide I and II peak area and ratio of amide I to II were increased linearly; although no difference existed in $\alpha$-helix and $\beta$-sheet height among the combinations, the ratio of $\alpha$-helix to $\beta$-sheet height was changed quadratically; 3 ) in the in situ 48-h residue samples, amide I and amide II peak area intensities were increased linearly and the ratio of amide I to II peak area was decreased linearly from 4.28 to $2.63 ; \alpha$-helix and $\beta$-sheet height of rumen residues were similar among 5 feed combinations; and 4) the ratio of $\alpha$-helix to $\beta$-sheet height in original feed combinations was strongly correlation with protein chemical and nutrient profiles, but the ratio of amide I to II area had no significant correlation with all items that were tested; no correlation was found between the ratio of $\alpha$-helix to $\beta$-sheet height of the in situ rumen residues and protein chemical and nutrient profiles. In conclusion, by integration of hulless barley with bioethanol coproduct of wheat DDGS, feed quality in combined feeds was improved and more optimized. Adding wheat DDGS increased linearly $\mathrm{CP}$, truly digestible $\mathrm{CP}$, rumen-degradable protein, rumen-undegradable protein, DVE, and OEB values in combined feeds. The molecular spectral differences of protein molecular structures (amide I and II area intensities, the ratio of amide I to amide II, and the ratio of $\alpha$-helix to $\beta$-sheet height among feed combinations) were detected among the combinations. This may partially explain the biological differences in protein chemical profiles and protein utilization and availability in dairy cattle. In the original combined feeds, protein $\alpha$-helix-to- $\beta$-sheet ratio had significant correlations with protein chemical and nutrient profiles, but in in situ 48-h residue samples, protein amide I-to-II ratio had significant correlations with protein chemical and nutrient profiles. This study may provide an insight into how to more efficiently use hulless barley grain (high energy and high degradation rate) and wheat DDGS (high metabolizable protein 
and low degradation rate) in beef and dairy production systems.

Key words: protein molecular structure, truly absorbed protein in small intestine, hulless barley, wheat dried distillers grains with solubles

\section{INTRODUCTION}

Barley has an attractive energy and protein content, which results in barley being one of the important ingredients in TMR of beef and dairy cattle. However, it has a high degradation rate and high degradability (Ørskov, 1986), which can result in 3 problems: 1) digestive disorders like bloat, SARA as well as laminitis, which can led to death (Nocek and Tamminga, 1991; Givens et al., 1993) and cause great financial losses; 2) an imbalance in N:energy ratio, which can impair microbial protein synthesis in the rumen and result in unnecessary energy losses and increased extra feed cost; 3) inefficient feed utilization, which can cause nutrient losses in the manure and add extra environmental pressure. So, optimal barley utilization strategies are needed. In the literature, many efforts have been made to optimize the use of barley grain in cattle (Gibson et al., 1994; Mathison, 1996; Rode et al., 1999), which mainly focus on adding fiber enzyme and processing methods. Today, various dried distillers grains with solubles (DDGS) are produced during bioethanol production (Government of Alberta, 2010). Because of the starch being removed and the other components being concentrated, the characteristics of high protein, high fiber, high fat, and low starch makes DDGS an attractive ingredient in diets for cattle (Spiehs et al., 2002; Klopfenstein et al., 2008). More and more research has been done to evaluate chemical profiles, protein and energy fractions, in situ rumen degradation kinetics, the truly digested protein supply, and the degraded protein balance, not only in various barley grains (Khorasani et al., 2000; Koenig et al., 2003; Yu et al., 2003) but also in various DDGS (Nuez-Ortín and Yu, 2009, 2010a,b).

Recent publications indicated big biological differences in protein availability between barley and bioethanol coproducts, which are closed related not only in their total protein content, but also in their inherent protein structures, including protein amide I and amide II, $\alpha$-helix and $\beta$-sheet intensity in terms of spectral peak area and height, as well as their ratios (Yu, 2007; Doiron et al., 2009; Yu and Nuez-Ortín, 2010). The molecular structural differences can be detected by using a novel approach: synchrotron-based infrared microspectroscopy (SR-IMS) or other forms of molecular spectroscopy [e.g., diffuse reflectance infrared Fourier transform (DRIFT) or Fourier transform infrared at- tenuated total reflectance (FT/IR-ATR)]. The molecular structure makeup can partly explain protein nutrient supply in ruminants from autoclaved Vimy flaxseed (Doiron et al., 2009). However, to date, no research has been conducted to optimize hulless barley quality by integration with wheat DDGS and to reveal their protein molecular structure spectral profile changes in combined feeds in relation to protein utilization and availability in the rumen and the small intestine in dairy cattle.

The synchrotron-based infrared microspectroscopy can be used to study protein structure for a single feed or seed. It is difficult to use this method to study combined feeds, which are common in dairy feeding. The objectives of this study were to investigate effects of feed combinations (hulless barley with wheat DDGS) at various ratios on 1) protein chemical profiles; 2) protein subfractions, partitioned using the Cornell Net Carbohydrate and Protein System (CNCPS); 3) truly digestible $\mathrm{CP}$ (tdCP) and total digestible nutrients at maintenance level $\left(\mathbf{T D N}_{\mathbf{1}}\right)$ using the NRC (2001) summary approach; 4) in situ rumen protein degradation kinetics; 5) predicted truly digested protein supply in the small intestine (DVE) and degraded protein balance in the rumen (OEB) by the DVE/OEB system or NRC (2001) model; and 6) protein molecular structure spectral differences in terms of amide I and amide II intensities and their ratios, $\alpha$-helix and $\beta$-sheet intensities and their ratios of both original samples (containing more easily digested protein), and in situ 48-h residual samples (containing undigested or uneasily digested protein). The correlations between protein molecular structure spectra and protein chemical and nutrient profiles and protein utilization and availability were also investigated in these combined feeds. The hypothesis of this study was that the bioethanol coproduct of wheat DDGS could act as a natural feed additive to slow down the extremely fast degradation rate in hulless barley and, through feed combination, protein chemical and nutrient profiles could be changed and optimized. The protein molecular structure changes were associated with protein utilization and availability.

\section{MATERIALS AND METHODS}

\section{Hulless Barley and Wheat DDGS Combinations}

Hulless barley cultivar CDC McGwire (obtained from the Crop Development Center, University of Saskatchewan, Saskatoon, SK, Canada) and bioethanol coproduct [pure wheat DDGS (obtained from a Saskatchewan bioethanol plant)] were combined into 5 different combined feeds at 5 different ratios (hulless barely:pure 
wheat DDGS: 100:0, 75:25, 50:50, 25:75, and 0:100). The combined feeds were named B100, B75WD25, B50WD50, B25WD75, and WD100, respectively, according to hulless barley-to-wheat DDGS ratios.

\section{Molecular Spectroscopic Investigation}

Molecular spectroscopic experiments were performed at the Department of Animal and Poultry Science, University of Saskatchewan. The molecular spectrum data were collected from 5 hulless barley and wheat DDGS combinations using a JASCO FT/IR-ATR-4200 spectrometer (JASCO Corp., Tokyo, Japan). At the same time, the molecular spectrum data of the relative in situ 48-h residue samples were also collected using a JASCO FT/IR-ATR-4200 spectrometer. Ten replicate samples were randomly determined for each treatment. Thirty-two scans per sample were collected in the midinfrared range from 4,000 to $700 \mathrm{~cm}^{-1}$ in transmission mode at a spectral resolution of $4 \mathrm{~cm}^{-1}$. The collected spectra were corrected against air as background.

\section{Univariate Molecular Spectral Analysis}

The spectral data analysis was conducted using OMNIC 7.2 software (Spectra Tech, Madison, WI). Protein amide I and II peak area, amide I and II peak height, and $\alpha$-helix and $\beta$-sheet peak height intensities and their ratios were determined. Chemical function groups (amide I and II) were identified according to published reports (Yu, 2007). The analysis spectrum region in this study was ca. 1721 to $1,484 \mathrm{~cm}^{-1}$. The analysis spectrum regions of amide I and amide II in this study were ca. 1721 to $1,580 \mathrm{~cm}^{-1}$ and 1,580 to $1,484 \mathrm{~cm}^{-1}$, respectively. For the $\alpha$-helix and $\beta$-sheet, the peak fell within the range of ca. 1,648 to $1,658 \mathrm{~cm}^{-1}$ and ca. 1,620 to $1,640 \mathrm{~cm}^{-1}$, respectively. The ratio of amide I and II peak area and ratio of $\alpha$-helix and $\beta$-sheet peak height were calculated according to respective absorbance intensity values. The detailed discussion and questions on the model-fitted protein secondary structure and accuracy of prediction by the multi-peak modeling were reported previously (Yu, 2006).

\section{Multivariate Molecular Spectral Analyses}

The FT/IR protein spectral data of the hulless barley and wheat DDGS combinations were analyzed by agglomerative hierarchical cluster analysis (CLA) and principal component analysis (PCA) using Statistica 8.0 software (StatSoft Inc., Tulsa, OK). These CLA and PCA methods are able to classify and distinguish inherent protein structural differences among treat- ments, and then identify the main sources of variation within fingerprint spectra (ca. 1,721-1,475 $\mathrm{cm}^{-1}$; Yu et al., 2009).

\section{Animals and Diets}

Three nonlactating Holstein cows with flexible rumen cannulas (10-cm i.d.; Bar Diamond Inc., Parma, ID) were used in this study. The cows were individually fed twice daily at 0800 and $1600 \mathrm{~h}$ and received 20.5 $\mathrm{kg} / \mathrm{d}$ of a TMR (10.25 $\mathrm{kg}$ at each feeding time). The TMR was formulated according to the dairy nutrient requirements of the NRC (NRC, 2001), which consisted of $16 \mathrm{~kg}$ of barley silage (DM 29\%) and $4.5 \mathrm{~kg}$ of dairy concentrate (called DAC526), which contained $63.9 \%$ rolled barley, 35.0\% supplement (called DAC525), $1.0 \%$ mill mix, and $0.1 \%$ mold control. The supplement (DAC525) contained $31.5 \%$ soybean meal, $27.0 \%$ canola meal, $10.0 \%$ peas, $8.5 \%$ premix (University of Saskatchewan), $5.5 \%$ corn grain, $5.5 \%$ corn gluten meal, $4.7 \%$ sodium bicarbonate, $3.0 \%$ ground barley, $2.0 \%$ canola oil, $1.6 \%$ salt, and $0.7 \%$ Dynamate ( $\mathrm{K}$ and $\mathrm{Mg}$ sulfate; University of Saskatchewan). Water was supplied ad libitum. The in situ dairy experiment was approved by the Animal Care Committee of the University of Saskatchewan, and all animals were cared for in accordance with the guidelines of the Canadian Council on Animal Care (CCAC, 1993).

\section{Rumen Protein Degradation Kinetics}

Rumen protein degradation kinetic parameters were determined using the in situ method ( $\mathrm{Yu}$ et al., 2003). Before ruminal incubation, all samples were coarsely rolled using a Sven roller mill with roller gap of $0.5 \mathrm{~mm}$ (Apollo Machine and Products Ltd., Saskatoon, SK). Seven grams of each combination sample of hulless barley and wheat DDGS was placed into each numbered nylon bag (Nitex 03-41/31 monofilament open mesh fabric; Screentec Crop., Mississauga, Ontario, Canada) measuring $10 \mathrm{~cm} \times 20 \mathrm{~cm}$, with a pore size of $40 \mu \mathrm{m}$. The ratio of sample size to bag surface area was equal to $17.5 \mathrm{mg} / \mathrm{cm}^{2}$, which is within the range recommended (Nocek, 1988). A polyester mesh bag, which was $45 \mathrm{~cm}$ $\times 45 \mathrm{~cm}$ with a $90 \mathrm{~cm}$ length of rope to be anchored to the cannula, was used to hold the bags in the rumen. Sample bags were added to the polyester mesh bag according to the gradual addition-all out schedule and incubated for 48, 24, 12, 8, 4, and $0 \mathrm{~h}$ (Yu et al., 2000; Urdl et al., 2006). The multi-bags for each treatment at each incubation time in each experiment run were 2,2 , $2,3,3$, and 4 bags for incubation times $0,4,8,12,24$, and $48 \mathrm{~h}$, respectively. The maximum number of bags in 
the rumen at any one time was around 28. Treatment samples were randomly assigned to the 3 nonlactating cows in 2 experimental runs. After incubation, the bags were removed from the rumen and, including those samples for $0 \mathrm{~h}$, rinsed under cold water to remove excess ruminal contents. The bags were washed with cool water without detergent and subsequently dried at $55^{\circ} \mathrm{C}$ for $48 \mathrm{~h}$. Dry samples were stored in a refrigerated room $\left(4^{\circ} \mathrm{C}\right)$ until analysis.

Rumen degradation characteristics of $\mathrm{CP}$ were determined using the NLIN procedure of the statistical package (SAS Institute, 2005). The first-order kinetics equation (Ørskov and McDonald, 1979) for CP is as follows:

$$
\mathrm{R}(\mathrm{t})=\mathrm{U}+\mathrm{D} \times \exp ^{\left[-\mathrm{K}_{\mathrm{d}} \times\left(\mathrm{t}-\mathrm{T}_{0}\right)\right]}
$$

where $\mathrm{R}(\mathrm{t})$ is the residue of the incubated material after $\mathrm{t} \mathrm{h}$ of ruminal incubation (\%); $\mathrm{U}$ and $\mathrm{D}(\%)$ are the undegradable and potentially degradable fractions, respectively; $T_{0}$ is the lag time in $h$; and $K_{d}$ is the degradation rate in $\% / \mathrm{h}$.

\section{Chemical Analysis}

All of the combination samples (B100, B75WD25, B50WD50, B25WD75, and WD100) and residues for chemical analysis were ground through a 1-mm screen (Retsch ZM-1; Brinkmann Instruments Ltd., Mississauga, ON, Canada), and all samples were analyzed for chemical nutritional profiles according to standard procedures described by the Association of Official Analytical Chemists (AOAC, 1990). Dry matter (AOAC method 930.15; weighing residue after oven drying of samples at $135^{\circ} \mathrm{C}$ for $2 \mathrm{~h}$ ), ash (AOAC method 942.05; weighing residue after oven ashing of samples at $600^{\circ} \mathrm{C}$ overnight), ether extract (AOAC method 954.02; at least 5-h extraction of samples in diethyl ether and weighing residue after oven drying of the extract at $100^{\circ} \mathrm{C}$ for $30 \mathrm{~min}$ ), and CP (AOAC 984.13; using the Kjeldahl-N method) concentrations were measured, respectively. For starch, samples were ground through a $0.5-\mathrm{mm}$ screen and analyzed using the Megazyme Total Starch Assay Kit (Megazyme International Ireland Ltd., Bray, Co. Wicklow, Ireland) and by the $\alpha$-amylase/amyloglucosidase method (McCleary et al. 1997). Neutral detergent fiber (AOAC method 2002.04), ADF (AOAC method 973.18), and ADL were analyzed according to the filtration method (Van Soest et al., 1991). During NDF analysis, all samples needed to be extracted using about 2,000 $\mathrm{mL}$ of neutral detergent solution and then rinsed 3 times with hot water $\left(90-100^{\circ} \mathrm{C}\right)$. Before neutral detergent extraction and before the first and second rinses, $4.0 \mathrm{~mL}$ of heat-stable $\alpha$-amylase without sodium sulfite was used each time. The N-adjusted NDF was calculated as NDF-neutral detergent-insoluble CP (NDICP). The ADL was determined as the residue weight after soaking the ADF filter bag residue in $72 \%$ sulfuric acid for $3 \mathrm{~h}$ and then washing 9 times with water (the first 3 times with warm water, the second 3 times with cold water, and the last 3 times with distiller water), rinsing with acetone, and oven drying at $105^{\circ} \mathrm{C}$ for $2 \mathrm{~h}$. The NDICP and acid detergent-insoluble CP (ADICP) concentrations were determined by Kjeldahl-N analysis of the NDF and ADF filter residue, respectively (Licitra et al., 1996). Total buffer-soluble CP (SCP) was determined by incubating the sample with bicarbonate-phosphate buffer and filtering through Whatman \#54 filter paper (Roe et al., 1990). The NPN content was analyzed by precipitating true protein with tungstic acid after samples were soaked in a $0.3 \mathrm{~mol} / \mathrm{L}$ sodium tungsten oxide $\left(\mathrm{Na}_{2} \mathrm{WO}_{4}\right)$ solution for $30 \mathrm{~min}$, and calculated as the difference between total $\mathrm{N}$ and the $\mathrm{N}$ content of the residue after filtration. The total carbohydrate concentration was calculated according to NRC (2001).

\section{Protein Fraction Partitioning}

The CNCPS was used to partition CP of the combinations of hulless barley and wheat DDGS (Sniffen et al., 1992; Lanzas et al., 2007). The fractions of CP are fraction A (PA; rapidly degradable with an assumed degradation rate of infinity), fraction $\mathrm{B}$ (PB; true protein), and fraction $\mathrm{C}$ (PC; unavailable protein). The PA is represented by NPN. The PB is further divided into 3 fractions $\left(\mathbf{P B}_{1}, \mathbf{P B}_{2}\right.$, and $\left.\mathbf{P B}_{3}\right)$, which are believed to have different rates of degradation in the rumen (Sniffen et al., 1992; Pell and Overton, 2004). The $\mathrm{PB}_{1}$ is rapidly degradable protein in the rumen $\left(\mathrm{K}_{\mathrm{d}}=\right.$ $120-400 \% / \mathrm{h})$ and the value is estimated by SCP minus NPN $\left(\mathrm{PB}_{1}=\mathrm{SCP}-\mathrm{NPN}\right) ; \mathrm{PB}_{2}$ is intermediately degradable protein $\left(\mathrm{K}_{\mathrm{d}}=3-16 \% / \mathrm{h}\right)$. A little $\mathrm{PB}_{2}$ can escape to the lower gut, which is estimated by difference of feed CP and SCP minus NDICP $\left[\mathrm{PB}_{2}=\right.$ (feed $\mathrm{CP}-\mathrm{SCP})-\mathrm{NDICP}] ; \mathrm{PB}_{3}$ is slowly degraded in the rumen $\left(\mathrm{K}_{\mathrm{d}}=0.06-0.55 \% / \mathrm{h}\right)$ because it is combined with the plant cell walls; it is believed to escape the rumen in large proportion. The $\mathrm{PB}_{3}$ is calculated from NDICP minus ADICP $\left(\mathrm{PB}_{3}=\mathrm{NDICP}-\mathrm{ADICP}\right)$.

\section{Estimation of TDN}

The tdCP and $\mathrm{TDN}_{1 \times}$ were determined using the NRC (2001) summative approach. 


\section{Using the DVE/OEB System and NRC (2001) Model to Predict Potential Protein Nutrient Supply}

The DVE/OEB system (Tamminga et al., 1994) and NRC model (NRC, 2001) were used in this study for estimating the truly digested absorbed protein in the small intestine (DVE) and degraded protein balance(OEB). The detailed formulas were reported in previous studies (Yu et al. 2003; Yu, 2005).

In the DVE/OEB system, DVE stands for truly absorbed protein in the small intestine, contributed by 1) ruminally bypassed feed protein or ruminally undegraded feed CP (RUP $\left.{ }^{\mathbf{D V E}}\right) ; 2$ ) microbial protein synthesized in the rumen $\left(\mathbf{M C P}_{\mathbf{F O M}}\right)$, and (3) a correction for endogenous protein losses in the digestive tract (ENDP). The formula equation is DVE $(\mathrm{g} / \mathrm{kg}$ of $\mathrm{DM})=$ truly absorbed rumen-synthesized microbial protein in the small intestine $(\mathbf{A M C P})+$ truly absorbed rumen undegraded feed protein in the small intestine (ARUP) - ENDP. The OEB is the degraded protein balance, calculated as $\mathrm{OEB}(\mathrm{g} / \mathrm{kg}$ of $\mathrm{DM})=$ N_MCP - E_MCP, where N_MCP is the microbial protein synthesis potentially possible from available rumen-degradable $\mathrm{CP}$, based on RDP, and E_MCP is the microbial protein synthesis potentially possible from the energy extracted during anaerobic fermentation, based on fermentable OM, or TDN.

In the NRC (2001) model, total MP is contributed by 1) ruminally undegraded feed CP (RUP $\left.{ }^{\text {NRC }}\right), 2$ ) ruminally synthesized microbial $\mathrm{CP}\left(\mathbf{M C P}^{\mathrm{NRC}}\right)$, and (3) endogenous CP. The formula is MP ( $\mathrm{g} / \mathrm{kg}$ of $\mathrm{DM}$ ) $=\mathrm{ARUP}+\mathrm{AMCP}+\mathrm{AECP}$. The $\mathbf{D P B}^{\mathrm{NRC}}$ is the degraded protein balance, based on the data from the NRC (2001) model, proposed by P. Yu (University of Saskatchewan), used comparison with OEB. The calculated formula is $\mathrm{DPB}^{\mathrm{NRC}}=\mathrm{EDCP}-1.18 \mathrm{MCP}_{\mathrm{TDN}}$.

\section{Statistical Analysis}

Protein Rumen Degradation and Intestinal Digestion Analysis. In the in situ degradation kinetics and predicted protein nutrient supply by the DVE/OEB system and NRC (2001) model, statistical analyses were performed using the MIXED procedure of SAS 9.2 (SAS Institute, 2005). The model used for the analysis was $Y_{i j}=\mu+P_{i}+R_{j}+e_{i j}$, where $Y_{i j}$ was an observation of the dependent variable $\mathrm{ij} ; \mu$ was the population mean for the variable; $\mathrm{P}_{\mathrm{i}}$ was the effect of combined feeds, as a fixed effect; $R_{j}$ was the in situ experimental run with 3 cows as a random effect; and $\mathrm{e}_{\mathrm{ij}}$ was the random error associated with the observation ij.

Protein Molecular Structure Spectral Data Analysis. Statistical analysis was performed using the
MIXED procedure of SAS 9.2 using a complete design. The model used for analysis was $Y_{i j}=\mu+a_{i}+\varepsilon_{i j}$, where $Y_{\mathrm{ij}}$ was an observation of the dependent variable $\mathrm{ij} ; \mu$ was the population mean for the variable; $a_{i}$ was the effect of the treatments ( 5 combinations), as a fixed effect; and $\varepsilon_{\mathrm{ij}}$ was the random error associated with the observation ij.

Correlation Analysis Between Protein Molecular Spectroscopic Features and Protein Chemical Profile and Utilization and Availability. The relationship between the changes in protein structure of amide I and II area and their ratios, $\alpha$-helix and $\beta$-sheet height and their ratios, and the changes in protein chemical composition, protein subfractions, in situ protein degradation kinetics, and predicted protein supply to dairy cattle among 5 combinations was analyzed using the PROC CCORR of SAS software (Liu and $\mathrm{Yu}, 2010)$. For all statistical analyses, significance was declared at $P<0.05$ and trends at $P \leq 0.10$. Treatment means were compared using the Tukey method.

\section{RESULTS AND DISCUSSION}

In this study, the combined feeds at 5 different ratios (hulless barely:pure wheat DDGS: 100:0, 75:25, 50:50, 25:75, and 0:100) were studied. In the dairy, it is not possible to use $100 \%$ hulless barley or $100 \%$ wheat DDGS as a cow diet. The $100 \%$ hulless barley and $100 \%$ DDGS were included in this study for comparison purposes. However, for barley, in beef finishing diets, it is normal that a diet contains $90 \%$ barley. So, the treatment information with high barley content that we provided here is useful for beef cattle.

\section{Changes in Protein Chemical Profiles Through Feed Combination (Hulless Barley with Bioethanol Coproduct of Wheat DDGS)}

The chemical analysis results of the 5 combinations of hulless barley with wheat DDGS are presented in Table 1. With increasing wheat DDGS level, the protein chemical profile was changed. The CP, NDICP, ADICP and NPN contents were increased, but soluble $\mathrm{CP}$ content was reduced. The CP content was increased about 3 times from $147 \mathrm{~g} / \mathrm{kg}$ of DM in B100 to $392 \mathrm{~g} /$ $\mathrm{kg}$ of DM in WD100. The SCP was decreased from 374 to $277 \mathrm{~g} / \mathrm{kg}$ of CP. Meanwhile, the contents in NDICP and ADICP were increased 5 and 32 times from B100 (99 and $5 \mathrm{~g} / \mathrm{kg}$ of CP) to WD100 (512 and $152 \mathrm{~g} / \mathrm{kg}$ of $\mathrm{CP})$, respectively. Nonprotein nitrogen was increased about 2 times from 505 (in B100) to $974 \mathrm{~g} / \mathrm{kg}$ of SCP in WD100. Through the combination of hulless barley with wheat DDGS, total carbohydrates and starch 
linearly decreased, whereas $\mathrm{CP}$ and NDF linearly increased, which may result in more optimal energy-tonitrogen balance and result in reducing the incidence of SARA and laminitis.

\section{Changes in Protein Subfractions Through Feed Combination (Hulless Barley with Bioethanol Coproduct of Wheat DDGS)}

The results of $\mathrm{CP}$ subfractions partitioned by the CNCPS model are presented in Table 1. According to the CNCPS model, protein subfractions are highly related to protein degradation behavior. The results showed that $\mathrm{PA}, \mathrm{PB}_{3}$, and $\mathrm{PC}$ were increased, whereas $\mathrm{PB}_{1}$ and $\mathrm{PB}_{2}$ were decreased from B100 to WD100. The fraction PA is rapidly degradable, with an assumed degradation rate of infinity in the rumen in relation to NPN. The PA fraction was increased from 154 to $270 \mathrm{~g} / \mathrm{kg}$ of CP. The PA fraction in B100 $(189 \mathrm{~g} / \mathrm{kg}$ of $\mathrm{CP})$ was lower than that in WD100 $(270 \mathrm{~g} / \mathrm{kg}$ of $\mathrm{CP})$. Fraction $\mathrm{PB}_{1}$ is rapidly degradable true protein and can be degraded by digestion enzymes in the rumen. Fraction $\mathrm{PB}_{2}$ is intermediately degradable true protein; only a little $\mathrm{PB}_{2}$ can escape to the lower gut. The fractions $\mathrm{PB}_{1}(7 \mathrm{~g} / \mathrm{kg}$ of $\mathrm{CP})$ and $\mathrm{PB}_{2}(211 \mathrm{~g} /$ $\mathrm{kg}$ of $\mathrm{CP}$ ) in wheat DDGS were approximately $3.8 \%$ and $40.0 \%$ of those in hulless barley $\left(\mathrm{PB}_{1}, 185 \mathrm{~g} / \mathrm{kg}\right.$ of $\mathrm{CP}$ and $\mathrm{PB}_{2}, 528 \mathrm{~g} / \mathrm{kg}$ of $\mathrm{CP}$ ). This indicated that the $\mathrm{CP}$ in hulless barley was subjected to be degraded rapidly, and mainly contribute $\mathrm{RDP}$ in the rumen. On the other hand, wheat DDGS had the highest $\mathrm{PB}_{3}$ fraction $(360 \mathrm{~g} / \mathrm{kg}$ of $\mathrm{CP})$, which was 4 times that of hulless barley $(94 \mathrm{~g} / \mathrm{kg}$ of $\mathrm{CP})$. The $\mathrm{PB}_{3}$ is slowly degraded and can escape the rumen in large proportion, so wheat DDGS can contribute more RUP in the rumen. In addition, because wheat DDGS has higher CP content than hulless barley, it could improve RDP and RUP in B75WD25, B50WD50, and B25WD75. Wheat DDGS also has a larger PC fraction than hulless barley. But $\mathrm{PC}$ is ADICP, which is highly resistant to breakdown by microbial and mammalian enzymes, so it is assumed to be unavailable to the animal (NRC, 2001). These results implied that wheat DDGS added extra PC to B75WD25, B50WD50, and B25WD75, which may negatively affect digestibility.

\section{Changes in tdCP and TDN Through Feed Combinations (Hulless Barley with Bioethanol Coproduct of Wheat DDGS)}

The results of tdCP and TDN, estimated using the NRC (2001) summary approach among feed combinations of hulless barley with wheat DDGS are presented in Table 1. In general, TDN and truly digestible nutrients reflect the energy value of a feedstuff. The results showed that hulless barley was lower in tdCP (147 vs. $368 \mathrm{~g} / \mathrm{kg}$ of DM) but higher in $\mathrm{TDN}_{1 \times}(870 \mathrm{vs} .797 \mathrm{~g} / \mathrm{kg}$ of DM) than wheat DDGS. When increasing inclusion of wheat DDGS in feed combination, $\mathrm{TDN}_{1 \times}$ linearly decreased, whereas tdCP linearly increased. The results indicate that adding wheat DDGS to hulless barley will dilute the energy, but truly digestible protein will greatly increase.

\section{Changes in Protein Rumen Degradation Kinetics Through Feed Combinations (Hulless Barley with Bioethanol Coproduct of Wheat DDGS)}

Each component of a feed has its own pattern of rumen degradation behaviors, because microbial protein synthesis in the rumen is strongly related to the availability of each feed component in the rumen. In modern feed formulation, the degradation characteristic can be used to optimize the composition of dairy diets (Tamminga et al., 1994, 2007). The results of in situ protein rumen degradation kinetics among feed combinations of hulless barley with wheat DDGS are presented in Table 2 . In the characteristics of in situ rumen protein degradation, no difference was observed in lag time $\left(\mathrm{T}_{0}\right), \mathrm{S}$, $\mathrm{D}$, and $\mathrm{U}$ fractions among feed combinations. But the degradation rate of $\mathrm{CP}$ was greatly decreased from 9.63 to $4.26 \% / \mathrm{h}$. With increasing inclusion level of wheat DDGS, both RDP and RUP estimated with the DVE/ OEB system (Tamminga et al., 1994) were significantly increased from 94 to $184 \mathrm{~g} / \mathrm{kg}$ of DM for RDP (2-fold increase) and 53 to $208 \mathrm{~g} / \mathrm{kg}$ of DM for RUP (4-fold increase). The fermentable OM was decreased from 632 to $521 \mathrm{~g} / \mathrm{kg}$ of DM (Table 2).

\section{Changes in Predicted Protein Nutrient Supply to Dairy Cattle Through Feed Combinations (Hulless Barley with Bioethanol Coproduct of Wheat DDGS), Using a Modeling Approach}

The changes in the truly absorbed protein supply, metabolic protein characteristics, and the degraded protein balance among feed combinations (of hulless barley with wheat DDGS), predicted using the DVE/ OEB system and the NRC (2001) model, are presented Table 2. Not only by using the DVE/OEB system (Tamminga et al., 1994) but also by using NRC (2001) modeling, RDP and RUP simultaneously and significantly increased from B100 to WD100.

Predicted AMCP was different among the treatments [from 60 to $50 \mathrm{~g} / \mathrm{kg}$ of DM in the DVE/OEB system and from 59 to $54 \mathrm{~g} / \mathrm{kg}$ of DM in the NRC (2001) 
PROTEIN MOLECULAR STRUCTURE IN COMBINED FEEDS

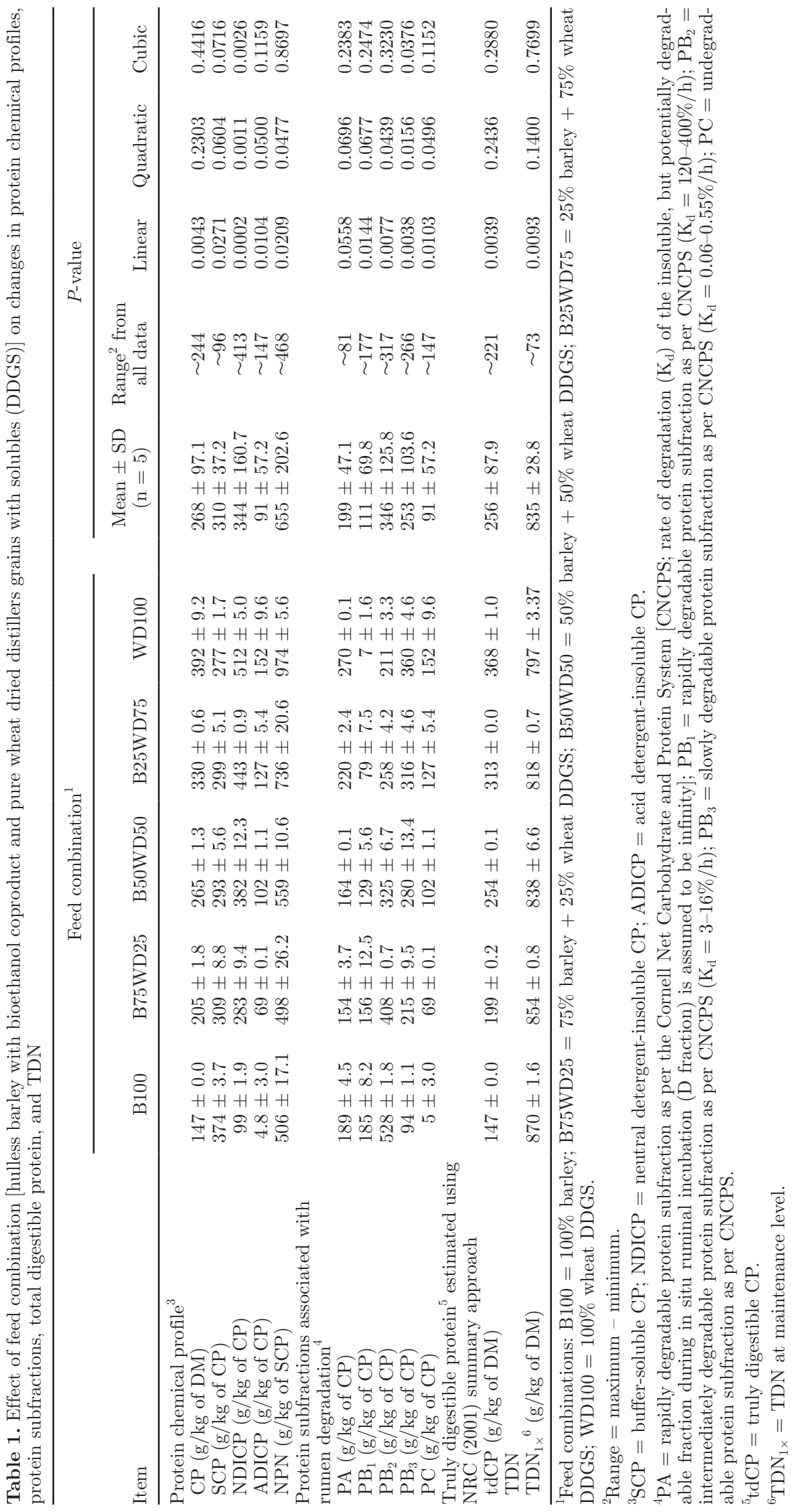




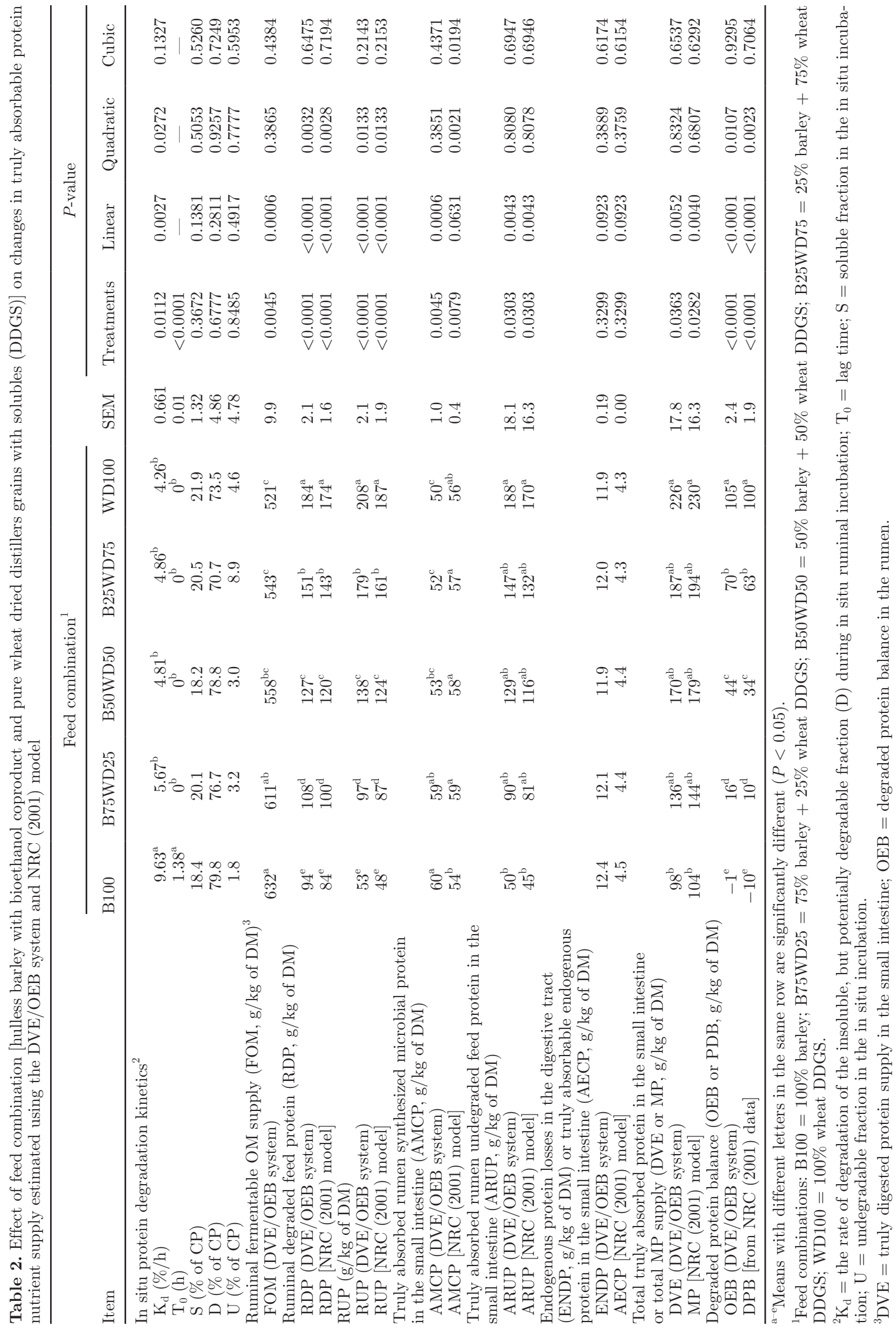


system]. The ARUP was greatly increased [from 50 to $188 \mathrm{~g} / \mathrm{kg}$ of DM in the DVE/OEB system and from 45 to $170 \mathrm{~g} / \mathrm{kg}$ of DM in the NRC (2001) system] without much effect on the endogenous protein (ENDP: $12 \mathrm{~g} /$ $\mathrm{kg}$ of DM in DVE/OEB or AECP: $4.4 \mathrm{~g} / \mathrm{kg}$ of DM in NRC; Table 2).

The values in DVE and MP were increased linearly [(DVE: 98 (B100) to 226 (WD100); MP: 104 (B100) to $230 \mathrm{~g} / \mathrm{kg}$ of DM (WD100)]. The OEB values were also increased significantly from B100 $(-1 \mathrm{~g} / \mathrm{kg}$ of DM) to WD100 (105 g/ $\mathrm{kg}$ of DM) in the DVE/OEB system or from -10 to $100 \mathrm{~g} / \mathrm{kg}$ of DM (estimated by using NRC data). Degraded protein balance reflects the (im) balance between microbial protein synthesis potentially possible from available rumen-degradable CP (based on RDP) and that potentially possible from the energy extracted during anaerobic fermentation (based on fermentable OM, or TDN) in the rumen (Tamminga et al., 1994). When it is positive, the value shows the potential loss of nitrogen from the rumen. When it is negative, microbial protein synthesis may be impaired, because of a shortage of nitrogen in the rumen. The optimum value of degraded protein balance in a ration is, therefore, zero or slightly above (Yu et al., 2003; Tamminga et al., 1994). The results reported here showed that hulless barley was not good, relative among the treatments, because its DVE was the lowest and OEB was negative. Although wheat DDGS had the highest DVE, it also had highest OEB (over $100 \mathrm{~g} / \mathrm{kg}$ of $\mathrm{DM}$ ), which is far more than zero and will cause more potential nitrogen loss in the rumen. By combining hulless barley (high energy content and lower true protein value) with wheat DDGS (high available protein), the nutrient quality of combinations was more optimized than pure hulless barley or pure wheat DDGS. The combination, with inclusion of wheat DDGS to $25 \%$ in hulless barley, provided more truly digested protein to the small intestine and maintained a positive degraded protein balance in the rumen.

It needed to be mentioned that, in this study, the truly absorbed nutrient supply parameters were predicted using the DVE/OEB system and NRC (2001 model). Compared with an animal trial, this approach has a big advantage if you have too many treatments. It is impossible or impractical to do an animal trial with many treatments. The modeling approach is a fast way to screen numerous treatments. Another advantage is that the modeling approach can get rid of some noise effects, such as weather effects, animal variation effects, animal health effects, and gene type effects (TT, CT, or CC animals). The disadvantage is that the predicted data may be different from that of the animal trial. However, this is expected because the models were de- veloped based on thousands and thousands of animals with many trials and are not specific to individual animals or a small group of animals.

\section{Changes in Protein Molecular Structure Profiles Through Feed Combinations (Hulless Barley with Bioethanol Coproduct of Wheat DDGS)}

Traditional wet chemical analysis and in situ biological analysis can determine total protein composition, degradability, and digestibility in the gastrointestinal tract, but fail to detect protein inherent structure and molecular makeup due to destruction of barley and bioethanol coproduct protein structure during processing for chemical analysis. In previous research in our group, it was found that 2 barley varieties showed the same chemical composition, but significant different digestive behavior in ruminants, and 2 coproducts had similar levels of RUP, but actually had different availabilities of RUP (Yu et al., 2003; Yu and Nuez-Ortín, 2010). The DVE/OEB system (Tamminga et al., 1994, 2007) and NRC (2001) model cannot give an explanation. So, the molecular structure study was performed in this study to explore the protein molecular structure makeup in combined feeds of hulless barley with wheat DDGS in relation to protein digestibility and availability in cattle.

\section{Univariate Molecular Spectral Analysis of Protein Molecular Structure}

By using molecular spectroscopy, the results of protein structure and secondary structure spectral profiles of original combination samples of hulless barley with wheat DDGS and their relevant in situ 48-h rumen residue samples are presented in Tables 3 and 4 . The results show that 1) amide I area, amide II area, and the ratio of amide I to II area of original combination samples increased significantly from B100 to WD100 with increasing inclusion level of wheat DDGS. However, no difference was observed in the ratio of amide I to II between B75WD25, B50WD50, and B25WD75. Typically, differences of protein amide I and amide II infrared intensity in terms of peak area or height indicate quantitative differences in functional groups (or contents), whereas their ratios demonstrate differences in protein molecular structural makeup between biological tissues (Yu et al., 2010). In this study (Table 3 ), it was found that in original combination samples, WD100 was significantly different from B100 (hulless barley) not only in quantitative (or contents) but also in protein molecular structural makeup. 2) Amide I peak area and amide II peak area intensities of in situ 48-h 
residue samples were increased significantly, but the ratio of amide I to II area decreased significantly from B100 to WD100 (Table 4). A previous study (Yu and Nuez-Ortín, 2010) showed that among different types of DDGS samples from various sources, lower protein amide I-to-amide II ratio was associated with a higher RUP value in DDGS. However, in the current study, the results did not support previous findings. Wheat DDGS had a higher RUP but at the same time, it had a higher ratio of amide I to II area. The reason for the difference may be due to different types of feed samples that were investigated. In the previous study, the conclusion was made among different types of DDGS samples, but in the current study, the results came from combined feeds. They are completely different. 3) Comparing amide I and II area intensities of the original samples with the relevant in situ residue samples, the values of amide I area and amide II area intensities of in situ 48 -h residues were much less than those of the original combination samples (Tables 3 and 4). This indicated that a large amount of original protein in combined feed was degraded during rumen fermentation. And the difference in ratio of amide I to amide II between the original WD100 and their in situ 48-h residue sample was higher than that of other feed combinations; this may reflect that WD100 had much more feed protein that was degraded in the rumen, which may cause excess nitrogen supply (bigger OEB). 4) With regard to protein secondary structure, no difference was observed in $\alpha$-helix height and $\beta$-sheet height among the feed combinations in both original sample and relative in situ 48-h residue samples (Tables 3 and 4). However, there was a quadratic or cubic response between the ratio of $\alpha$-helix to $\beta$-sheet and inclusion level of hulless barley to wheat DDGS in original combined feeds and 48-h rumen residues, respectively. The results were not in accordance with our hypothesis (a linear increase), which indicated that protein degradability in the rumen may not only depend on original protein inherent molecular characteristics, but also depend on other biopolymer inherent structure or biological component matrix, or both.

\section{Multivariate Molecular Spectral Analysis of Protein Inherent Structure}

The results of CLA of protein amide I and II spectra in the fingerprint region ca. 1,721 to $1,475 \mathrm{~cm}^{-1}$ obtained from combinations of barley with wheat DDGS are presented in Figure 1. With the wheat DDGS proportion increasing in the barley combinations, the spectral cluster of B50WD50, B25WD75, and WD100 were relatively different from B100 and B75WD25. But
B100 and B75WD25 did not discriminate into different clusters, indicating similarity in their structural makeup.

Figure 2 shows the results of PCA of protein amide I and II spectra in the fingerprint region ca. 1721 to 1475 $\mathrm{cm}^{-1}$ obtained from the combinations of hulless barley with wheat DDGS. The results indicate that the protein structural makeup of B25WD75 and WD100 were fully distinguished each other and were significantly different from B100, B50WD50, and B75WD25. The first and second principal components explain $96.80 \%$ and $1.77 \%$ of the total variance, but B100 and B75WD25 could not be grouped into separate ellipses.

\section{Protein Molecular Spectral Characteristics in Relation to Protein Chemical and Nutrient Profiles in Combined Feeds and Incubation Residues}

Pearson correlations between protein structural spectral characteristics, determined by using the molecular spectroscopy and protein chemical profile, protein subfractions, truly digestible protein, in situ protein degradation kinetics, and predicted protein nutrient supply in original feed combinations of hulless barley and wheat DDGS, are presented in Table 5 . The results show that amide I area had strong positive correlations with $\mathrm{CP}(\mathrm{R}=0.936, P<0.05)$, $\mathrm{PA}(\mathrm{R}=$ $0.911, P<0.05), \operatorname{tdCP}(\mathrm{R}=0.934, P<0.05), \mathrm{RDP}(\mathrm{R}$ $=0.975, P<0.01)$, RUP $(\mathrm{R}=0.904, P<0.05)$, ARUP $(\mathrm{R}=0.916, P<0.05)$, DVE $(\mathrm{R}=0.919, P<0.05)$, and $\mathrm{OEB}(\mathrm{R}=0.979, P<0.05)$. On the contrary, amide I area had strong negative correlations with $\mathrm{PB}_{1}$ $(\mathrm{R}=-0.988, P<0.05)$; however, the ratio of amide I to amide II area had no correlations with any item of protein chemical profile, protein subfractions, truly digestible protein, in situ protein degradation kinetics, and predicted protein nutrient supply, maybe because amide II is involved with other functional groups (biomolecular and biopolymer). These results are not the same as those from a previous report ( $\mathrm{Yu}$ and NuezOrtín, 2010); this is because of the different types of feeds that were investigated in the 2 different studies (pure DDGS vs. combined feeds). Also, $\alpha$-helix height had strong positive correlations with $\mathrm{CP}, \mathrm{PB}_{3}, \mathrm{PC}$, tdCP, RDP, RUP, DVE, and OEB $(P<0.05)$, whereas it had strong negative correlations with $\mathrm{PB}_{1} ; \mathrm{PB}_{2}$; the rate of degradation of the insoluble, but potentially degradable fraction during in situ ruminal incubation (D fraction) in CP $\left(\mathrm{Kd} \_\mathrm{CP}\right)$; and AMCP $(P<0.05)$. The $\beta$-sheet height was similar to that of the $\alpha$-helix. Subsequently, the ratio of $\alpha$-helix to $\beta$-sheet had significantly negative correlations with $\mathrm{CP}, \mathrm{PA}, \mathrm{PB}_{3}, \mathrm{PC}$, tdCP, RDP, RUP, ARUP, DVE, and OEB $(P<0.05)$, 
PROTEIN MOLECULAR STRUCTURE IN COMBINED FEEDS
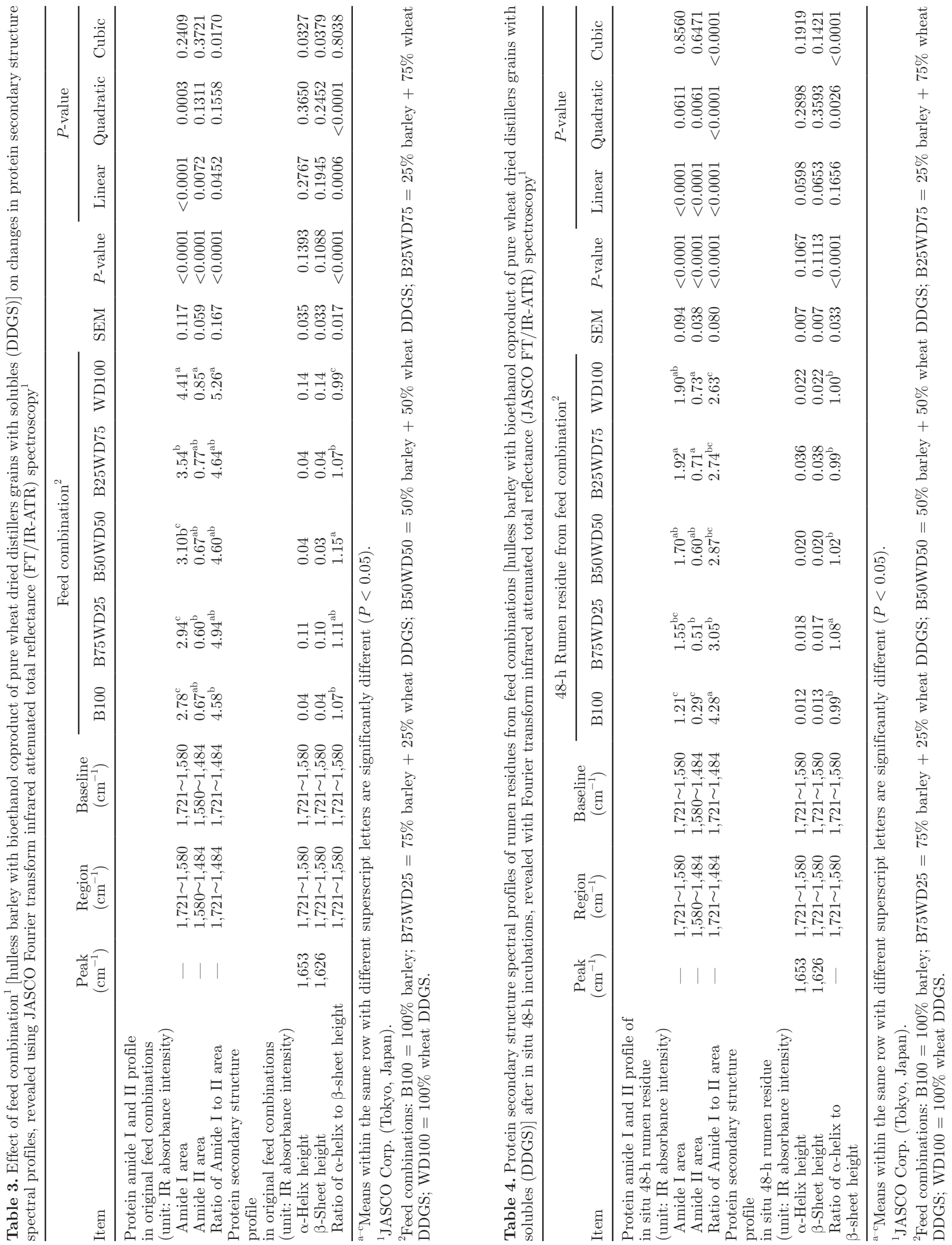


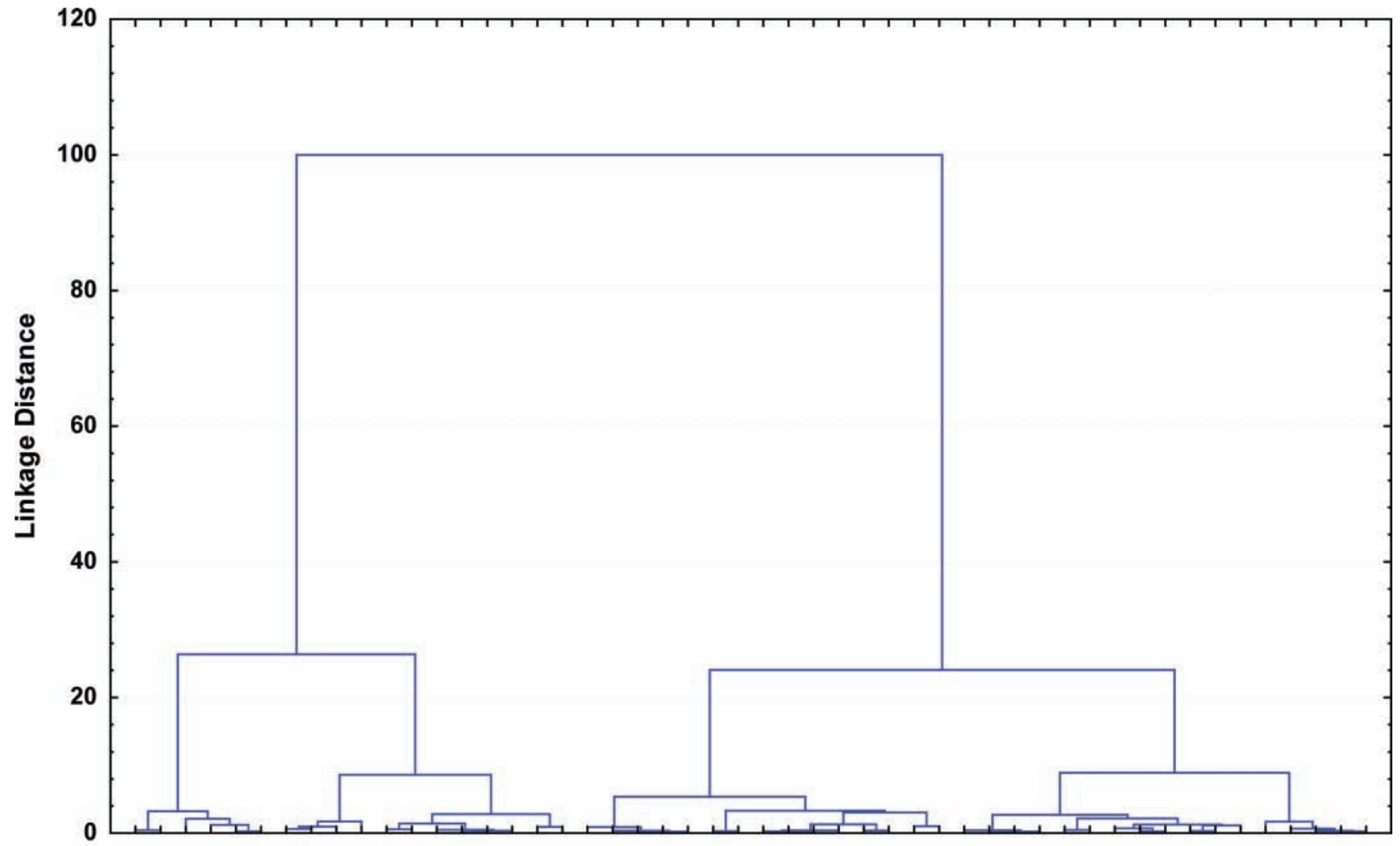

55555555552444444444333333333341122221122211112121

Figure 1. Cluster analysis (CLA) of Fourier transform infrared (FT/IR) protein amide I and II spectra obtained from 5 combinations of barley with wheat dried distillers grains with solubles [DDGS; CLA analysis: 1) fingerprint spectral region: ca. $\left.1,721-1,475 \mathrm{~cm}^{-1} ; 2\right)$ distant method: Euclidean; and 3) cluster method: Ward's algorithm]. Tree diagram for 50 cases: $1=100 \%$ barley; $2=75 \%$ barley $+25 \%$ wheat DDGS; $3=$ $50 \%$ barley $+50 \%$ wheat DDGS; $4=25 \%$ barley $+75 \%$ wheat DDGS; and $5=100 \%$ wheat DDGS. Color version available in the online PDF.

but strong positive correlations with $\mathrm{PB}_{1}, \mathrm{~PB}_{2}$, and $\operatorname{AMCP}(P<0.05)$.

To further investigate the protein spectral characteristics in relation to protein chemical profiles and protein degradation kinetics and availability, the correlation of protein spectral data of in situ 48-h residues of combined feeds (hulless barley with wheat DDGS combinations) in relation to protein chemical profile, protein subfractions, truly digestible protein, in situ protein degradation kinetics, and predicted protein nutrient supply were performed. We checked the protein structure in rumen residue samples because we wanted to know whether any protein was left. If protein was left, it should be undigested or uneasily digested protein. This residue protein was expected to be different in protein inherent structure from the original protein. We wanted to determine any relationship with chemical and nutrient profiles in the original samples, particularly with the unavailable protein $(\mathrm{U})$ or protein associated with cell wall fractions (such as $\mathrm{U}$ of $\mathrm{CP}$,
ADICP, NDICP, and PC fractions). The results are presented in Table 6 . The results showed that the correlations between amide I area and all items were just like those of the original combinations. Here, amide II was similar to amide I. However the ratio of amide I to amide II area had strong positive correlations with $\mathrm{PB}_{2}$ and Kd_CP, but strong negative correlations with $\mathrm{PB}_{3}$, PC, RUP, ARUP, and DVE. There was no correlation with OEB. Also, no correlation was found between the ratio of $\alpha$-helix to $\beta$-sheet and all parameters in terms of protein chemical composition, protein subfractions by CNCPS, truly digestible protein, in situ protein degradation kinetics, and predicted protein supply. These results may indicate that residue protein structural profile after in situ 48-h incubation not only depended on the protein molecular structure of original feed samples but also the rumen fermentation conditions, such as rumen microbial population, temperature, and $\mathrm{pH}$.

No study in the literature could be found to check rumen residue protein spectral profiles. No comparison 


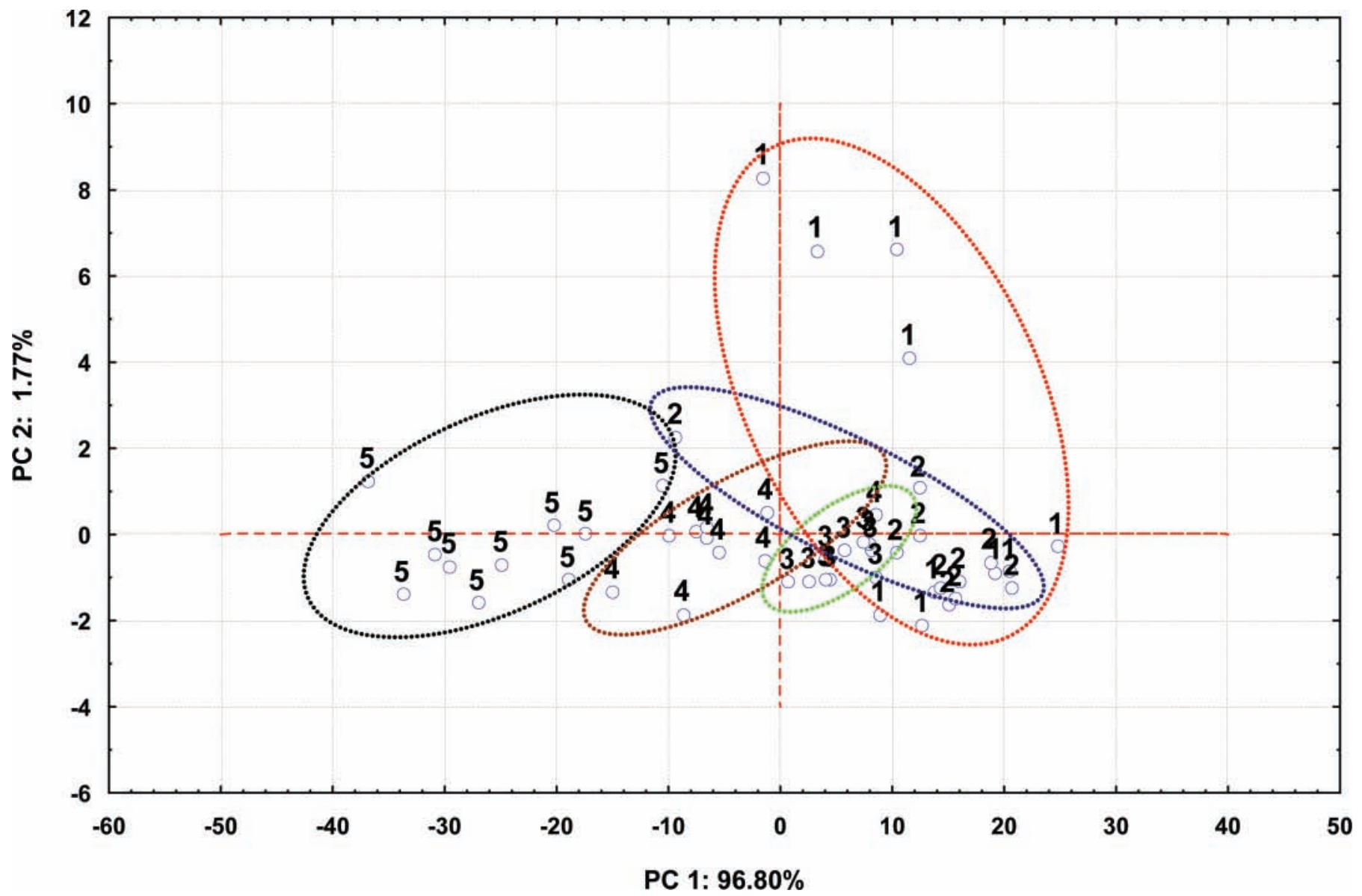

Figure 2. Principal component (PC) analysis of Fourier transform infrared (FT/IR) protein amide I and II molecular spectrum in fingerprint region ca. 1,721 to $1,475 \mathrm{~cm}^{-1}$ obtained from 5 combinations of barley and wheat dried distillers grains with solubles (DDGS). Projection of the cases on the factor plane $(1 \times 2): 1=100 \%$ barley; $2=75 \%$ barley $+25 \%$ wheat DDGS; $3=50 \%$ barley $+50 \%$ wheat DDGS; $4=25 \%$ barley $+75 \%$ wheat DDGS; and $5=100 \%$ wheat DDGS. Color version available in the online PDF.

could be made. Doiron et al. (2009) reported that Vimy flaxseed autoclave heated at $120^{\circ} \mathrm{C}$ for 20,40 , and 60 min significantly induced changes in protein molecular structure in the heated flaxseed. They found that the protein secondary structure $\alpha$-helix-to- $\beta$-sheet ratio had significant positive correlation with total intestinally absorbed protein supply (DVE value) and negative correlation with degraded protein balance (OEB value). In the current combined feeds study, it was also found that the protein secondary structure $\alpha$ - helix to $\beta$-sheet ratio had significant negative correlation with the DVE and OEB values. Why some molecular structures of protein fractions are positively correlated with the protein value and some are negatively correlated with the protein value is still not clear. However, this may be strongly related to protein content and protein inherent structure. Some unique spectra of protein are more associated with protein content in the tissue, some unique spectra of protein are mainly associated with protein make-up/conformation and molecular bonding (double bond or single bonding), and some spectra of protein may overlap with other functional groups (for example, amide II with lignin ring). It is still not clear why. More research is needed. In both studies, the data sets were relatively small. Further study with a large sample size is needed to confirm these interesting findings and develop potential prediction equations for fast truly absorbed protein value evaluation.

\section{CONCLUSIONS}

It was concluded that by integration of hulless barley with a bioethanol coproduct of pure wheat DDGS, the feed qualities in combined feeds were significantly changed compared with single feed hulless barley or wheat DDGS and were more optimized. Adding pure wheat DDGS linearly increased DVE and OEB values in the combined feeds. The results confirmed our 


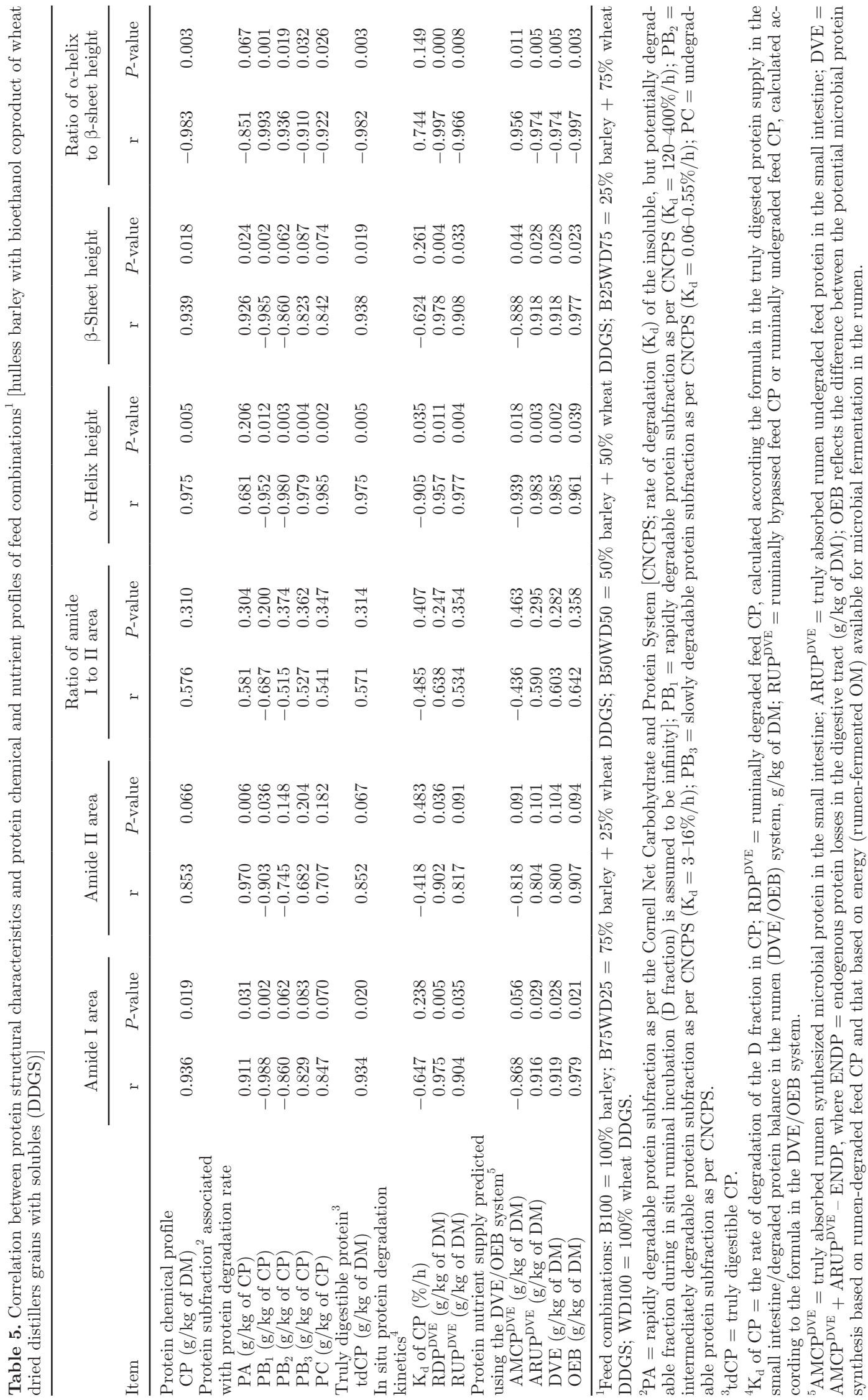


PROTEIN MOLECULAR STRUCTURE IN COMBINED FEEDS

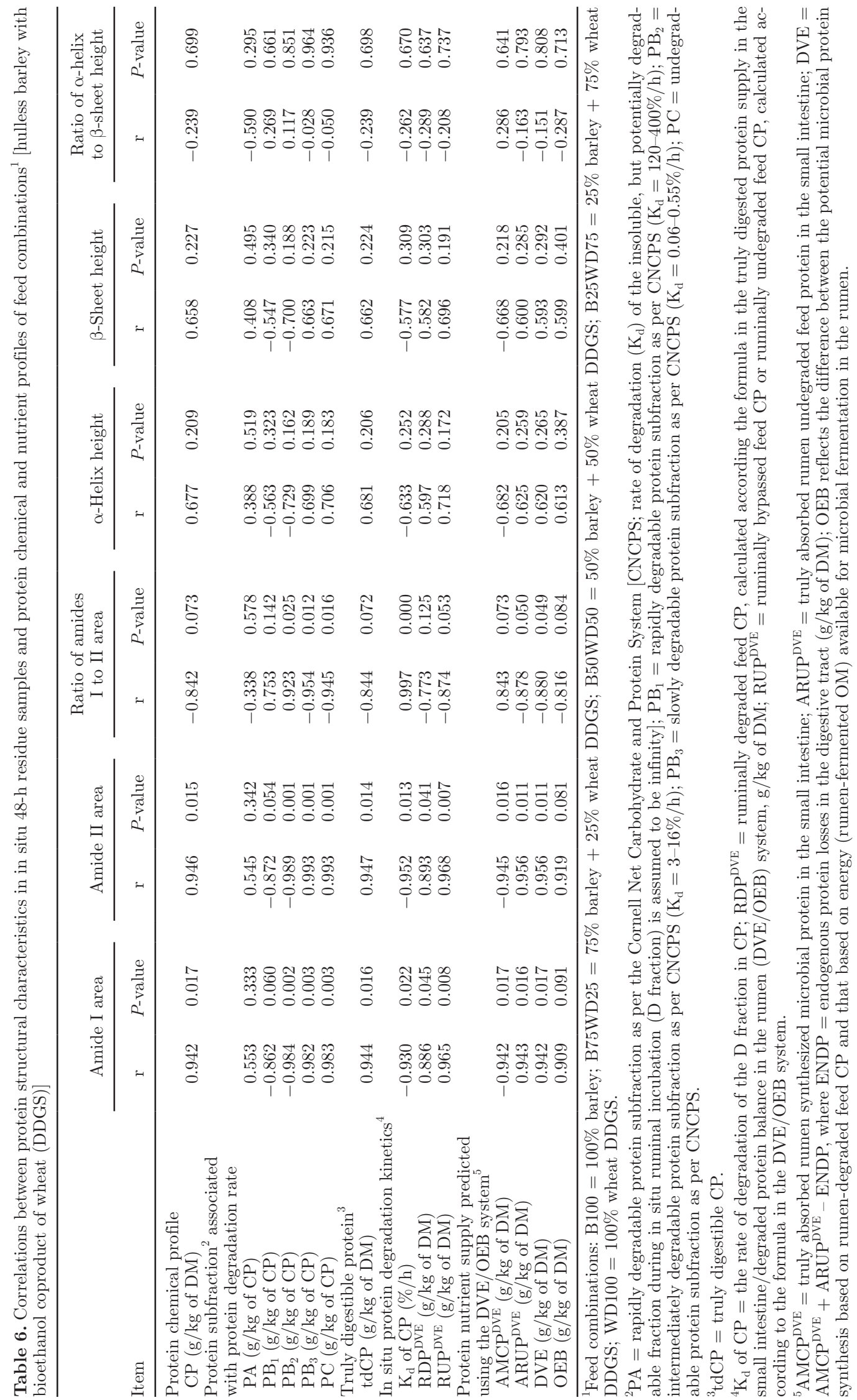


hypothesis that wheat DDGS could be used as a feed additive to slow down the barley degradation rate. The protein molecular structure spectral profiles in combined feed have a significant relationship with nutrient availability. Further study with large samples is needed to validate the findings and develop potential predictive equations. This study may provide new insight into how to more efficiently use hulless barley grain (high energy) and wheat DDGS (high protein) in beef and dairy production systems.

\section{ACKNOWLEDGMENTS}

We are grateful to the Agricultural Development Fund, Beef Cattle Research Council-Agriculture and Agri-Food Canada (BCRC-AAFC, Ottawa, Ontario, Canada), Natural Sciences and Engineering Research Council of Canada (NSERC, Ottawa, Ontario, Canada), and Ministry of Agriculture Strategic Research Program Chair for financial support of the feed research program. The authors thank Z. Niu, B. Liu, and A. Jonker (all in our research group at the University of Saskatchewan) for research assistance.

\section{REFERENCES}

AOAC. 1990. Official Methods of Analysis. Association of Official Analytical Chemists, Washington, DC.

CCAC (Canadian Council on Animal Care). 1993. Guide to the Care and Use of Experimental Animals. 2nd ed. Canadian Council on Animal Care, Ottawa, ON, Canada.

Doiron, K. J., P. Yu, C. R. Christensen, D. A. Christensen, and J. J. McKinnon. 2009. Detecting molecular changes in Vimy flaxseed protein structure using synchrotron FTIRM and DFTIR spectroscopic techniques: Structural and biochemical characterization. Spectroscopy 23:307-322.

Gibson, L. A., J. G. P. Bowman, L. E. Oberthur, and T. K. Blake. 1994. Determination of genetic markers associated with ruminant digestion of barley. Proc. West. Sec. Am. Soc. Anim. Sci. 45:317320 .

Givens, D. I., P. Clark, D. Jacklin, A. R. Moss, and C. R. Savery. 1993. Nutritional aspects of cereals, cereal grain by-products and cereal straw for ruminants. Home Grown Cereals Authority (HGCA) Report No. HGCA-RR-24. HGCA, London, UK.

Government of Alberta. 2010. Canadian biofuel industry: Western Canada perspective and opportunities. Accessed June 1, 2010. http://www.thebioenergysite.com/articles/70/canadian-biofuelindustry-western-canada-perspective-and-opportunities.

Khorasani, G. R., J. Helm, and J. J. Kennelly. 2000. In situ rumen degradation characteristics of sixty cultivars of barley grain. Can. J. Anim. Sci. 80:691-701.

Klopfenstein, T. J., G. E. Erickson, and V. R. Bremer. 2008. Boardinvited review: Use of distillers by-products in the beef cattle feeding industry. J. Anim. Sci. 86:1223-1231.

Koenig, K. M., K. A. Beauchemin, and L. M. Rode. 2003. Effect of grain processing and silage on microbial protein synthesis and nutrient digestibility in beef cattle fed barley-based diets. J. Anim. Sci. 81:1057-1067.

Lanzas, C., C. J. Sniffen, S. Seo, L. O. Tedeschi, and D. G. Fox. 2007. A revised CNCPS feed carbohydrate fractionation scheme for formulating rations for ruminants. Anim. Feed Sci. Technol. 136:167-190.
Licitra, G., T. M. Hernandez, and P. J. Van Soest. 1996. Standardization of procedures for nitrogen fractionation of ruminant feeds. Anim. Feed Sci. Technol. 57:347-358.

Liu, N., and P. Yu. 2010. Characterization of the microchemical structure of seed endosperm within a cellular dimension among six barley varieties with distinct degradation kinetics, using ultraspatially resolved synchrotron-based infrared microspectroscopy. J. Agric. Food Chem. 58:7801-7810.

Mathison, G. W. 1996. Effects of processing on the utilization of grain by cattle. Anim. Feed Sci. Technol. 58:113-125.

McCleary, B. V., T. S. Gibson, and D. C. Mugford. 1997. Measurement of total starch in cereal products by amyloglucosidase- $\alpha$ amylase method: Collaborative study. J. AOAC Int. 80:571-579

Nocek, J. E. 1988. In situ and other methods to estimate ruminal protein and energy digestibility: A review. J. Dairy Sci. 71:20512069

Nocek, J. E., and S. Tamminga. 1991. Site of digestion of starch in the gastrointestinal tract of dairy cows and its effect on milk yield and composition. J. Dairy Sci. 74:3598-3629.

NRC. 2001. Nutrient Requirements of Dairy Cattle. 7th rev. ed. National Academy of Science, Washington, DC.

Nuez Ortín, W. G., and P. Yu. 2009. Nutrient variation and availability of wheat DDGS, corn DDGS and blend DDGS from bioethanol plants. J. Sci. Food Agric. 89:1754-1761.

Nuez-Ortín, W. G., and P. Yu. 2010a. Estimation of ruminal and intestinal digestion profiles, hourly effective degradation ratio and potential $\mathrm{N}$ to energy synchronization of co-products from bioethanol processing. J. Sci. Food Agric. 90:2058-2067.

Nuez-Ortín, W. G., and P. Yu. 2010b. Effects of bioethanol plant and coproduct type on the metabolic characteristics of the proteins in dairy cattle. J. Dairy Sci. 93:3775-3783.

Ørskov, E. R. 1986. Starch digestion and utilization in ruminants. J. Anim. Sci. 63:1624-1633.

Ørskov, E. R., and I. McDonald. 1979. The estimation of protein degradability in the rumen from incubation measurements weighed according to rate of passage. J. Agric. Sci. (Camb.) 92:499-503.

Pell, A. N., and T. R. Overton. 2004. The Cornell Net Carbohydrate and Protein System model for evaluating herd nutrition and nutrient excretion. Anim. Feed Sci. Technol. 112:29-78.

Rode, L. M., W. Z. Yang, and K. A. Beauchemin. 1999. Fibrolytic enzyme supplements for dairy cows in early lactation. J. Dairy Sci. 82:2121-2126.

Roe, M. B., C. J. Sniffen, and L. E. Chase. 1990. Techniques for measuring protein fractions in feedstuffs. Pages $81-88$ in Proc. Cornell Nutrition Conference, Ithaca, NY.

SAS Institute. 2005. User's Guide: Statistics. Version 9.1.3. SAS Institute Inc., Cary, NC.

Sniffen, C. J., J. D. O'Connor, P. J. Van Soest, D. G. Fox, and J. B. Russell. 1992. A net carbohydrate and protein system for evaluating cattle diets: II. Carbohydrate and protein availability. J. Anim. Sci. 70:3562-3577.

Spiehs, M. J., M. H. Whitney, and G. C. Shurson. 2002. Nutrient database for distillers dried grains with solubles produced from new ethanol plants in Minnesota and South Dakota. J. Anim. Sci. 80:2639-2645.

Tamminga, S., G. G. Brandsma, J. Dijkstra, G. van Duinkerken, A. M. van Vuuren, and M. C. Blok. 2007. Protein evaluation for ruminants: The DVE/OEB 2007 system. CVB documentation report no. 53. CVB, Lelystad, the Netherlands.

Tamminga, S., W. M. Van Straalen, A. P. J. Subnel, R. G. M. Meijer, A. Steg, C. J. G. Wever, and M. C. Blok. 1994. The Dutch protein evaluation system: The DVE/OEB-system. Livest. Prod. Sci. 40:139-155.

Urdl, M., L. Gruber, J. Häusler, G. Maierhofer, and A. Schauer. 2006. Influence of distillers dried grains with solubles (Starprot) in dairy cow feeding. Slovak J. Anim. Sci. 39:43-50.

Van Soest, P. J., J. B. Robertson, and B. A. Lewis. 1991. Methods for dietary fiber, neutral detergent fiber, and nonstarch polysaccharides in relation to animal nutrition. J. Dairy Sci. 74:3583-3597.

$\mathrm{Yu}, \mathrm{P}$. 2005. Protein secondary structures ( $\alpha$-helix and $\beta$-sheet) at a cellular level and protein fractions in relation to rumen deg- 
radation behaviours of protein: A new approach. Br. J. Nutr. 94:655-665.

Yu, P. 2006. Synchrotron IR microspectroscopy for protein structure analysis: Potential and questions. Spectroscopy 20:229-251.

Yu, P. 2007. Molecular chemical structure of barley proteins revealed by ultra-spatially resolved synchrotron light source FTIR microspectroscopy: Comparison of barley varieties. Biopolymers 85:308-317.

Yu, P., H. C. Block, and K. Doiron. 2009. Understanding the differences in molecular conformation of carbohydrate and protein in endosperm tissues of grains with different biodegradation kinetics using advanced synchrotron technology. Spectrochim. Acta A Mol. Biomol. Spectrosc. 71:1837-1844.

Yu, P., J. O. Goelema, and S. Tamminga. 2000. Using the DVE/ OEB model to determine optimal conditions of pressure toasting on horse beans (Vicia faba) for the dairy feed industry. Anim. Feed Sci. Technol. 86:165-176.

Yu, P., J. A. Meier, D. A. Christensen, B. G. Rossnagel, and J. J. McKinnon. 2003. Using the NRC-2001model and the DVE/OEB system to evaluation nutritive values of Harrington (malting-type) and Valier (feed-type) barley for ruminants. Anim. Feed Sci. Technol. 107:45-60.

Yu, P., Z. Niu, and D. Damiran. 2010. Protein molecular structures and protein fraction profiles of new coproducts from bioethanol production: A novel approach. J. Agric. Food Chem. 58:34603464.

Yu, P., and W. G. Nuez-Ortín. 2010. Relationship of protein molecular structure to metabolisable proteins in different types of dried distillers grains with solubles: A novel approach. Br. J. Nutr. 104:1429-1437. 